\title{
The development of climate security discourse in Japan
}

\author{
Yasuko Kameyama $^{1}$ (D) Keishi Ono ${ }^{2}$
}

Received: 26 September 2019 / Accepted: 11 September 2020 / Published online: 25 September 2020

(c) The Author(s) 2020

\begin{abstract}
As the level of understanding about climate change has increased, the term "climate security" has been increasingly used in the rapidly growing literature on this subject. Although Japan has officially acknowledged the importance of tackling climate change, discussion of climate security has been almost nonexistent among Japanese governmental officials, politicians, and academics. Our aim was to trace discourses related to climate security in Japan to determine why so little exists in Japan and whether or not such discourse could suggest new areas for consideration to more comprehensively respond to the climate change problem. Because of different interpretations and uses of the term "climate security" in the existing literature, we first categorized existing approaches to climate security into four types and used this categorization to examine Japan's discourse from these perspectives. Two of the approaches, namely "long-term irreversible planetary changes" and "short-term abrupt risks to individuals", had been considered in Japan previously but without specific reference to the term climate security. The other two, "cause of conflict and violence" and "impacts to military and defense organizations", however, had not been used and need to be included in discussions of climate change in Japan. Some of the topics not discussed in Japan include indirect economic losses of Japanese industries via supply chains, loss of Japan's exclusive economic zone due to sea-level rise, and the potential inflow of refugees resulting from extreme weather patterns outside of Japan.
\end{abstract}

Keywords Climate security · Japan · Adaptation · Conflict · Disaster management

\section{Introduction}

Climate change is widely recognized as one of the most serious threats to human beings and ecosystems (IPCC 2014). Japan is one of many countries that have officially acknowledged that climate change is a serious global problem and that efforts to reduce greenhouse gas (GHG) emissions must occur immediately in all countries (Hattori 2007; KagawaFox 2012; Kameyama 2017). As our understanding of the climate change problem has increased, we have also witnessed a vast increase in the use of terms such as "climate

Handled by Keishiro Hara, Osaka University Center of Environmental Innovation Design for Sustainability, Japan.

Yasuko Kameyama

ykame@nies.go.jp

Keishi Ono

onokeishi@nids.go.jp

1 National Institute for Environmental Studies, 16-2, Onogawa, Tsukuba, Ibaraki, Japan

2 National Institute for Defense Studies, 5-1 Ichigayahonmuracho, Shinjuku-ku, Tokyo, Japan security", "climate change and security", and "climaterelated security" by experts and practitioners worldwide.

Debate on climate security, however, is almost nonexistent among Japanese government officials and politicians. The same can be said for Japanese academics, who have published very few journal articles or other material on climate security. This omission is rather extraordinary when compared to the actions of academics and government officials in other major economies, including other OECD member countries. Are Japanese practitioners and other stakeholders not interested in the notion of climate security, and if so, why not? Do they never discuss climate change from this perspective, or are they using other terminology to discuss essentially the same concepts? Should Japan "import" the notion of climate security to advance the implementation of climate policies?

Our aim was to answer these questions by collecting and categorizing relevant discourses in Japan that are within the scope of climate security as defined in other countries. The study consisted of two steps. First, we briefly summarized climate security discourse outside Japan and developed a categorization scheme to clarify different approaches and 
uses of the term. Although many articles have reviewed and categorized the diverse approaches related to the concept of climate security, none has examined how each approach could result in sending different messages to the audience as to what should be done to mitigate insecurity. Thus, this exercise was necessary to investigate which of the climate security notions has been characterized by other terms in the Japanese context. Second, we reviewed discourse in Japan that was related to the idea of climate security, placed the discourse within the context of the categorization developed in the first step, and analyzed how climate discourse in Japan is conducted without using the term "climate security". We also examined whether Japan has missed any aspects of the threats posed by climate change, or whether it has been able to deal with the climate security agenda but simply uses other terminology. Our intention was not to scrutinize bureaucratic politics among Japanese government agencies. Rather, our analysis focused exclusively on how Japanese government agencies perceived and dealt with the term climate security because they play central roles in the implementation of climate change policies (Kameyama 2017), and they are the ones who would start using new terminology if they considered it useful to enhance climate change policies.

Conceptualization of the term "security" as an overarching concept encompassing danger and risk is useful for analyzing "securitization" discourses in different countries. The essential feature of danger and risk is that both invoke a certain degree of threat. Whereas danger implies a short-term and imminent threat, risk denotes an uncertain threat (Diez et al. 2016). One of the questions relevant to the securitization of climate change is whether or not the concept of "climate security" can promote appropriate policies promptly to address the issues climate change proponents of securitization logic suggest. The logic of securitization holds that security is the move that takes "politics beyond the established rules of the game and frames the issue either as a special kind of politics or as above politics" (Buzan et al. 1998: 23). Securitization permits the breaking of established rules and the use of extraordinary measures if necessary (Buzan et al. 1998: 25). Given this definition of securitization, there are two conflicting normative assessments about linking climate change and security. Proponents of securitization argue that it can prioritize and accelerate climate change policies. Critics argue that it can lead to the militarization of climate policy and tilt toward adaptation measures to secure military facilities and prepare contingent action plans to cope with "climate refugees", thereby neglecting climate mitigation policies and human security aspects (Adger 2010; Diez et al. 2016: 3; Floyd and Matthew 2013: 280-4). In addition, critics say that the use of the term climate security may even obfuscate the important nuances of some climate-related risks. We discuss how this assessment may apply in the context of Japanese climate policy in the conclusion.

\section{Climate security approaches}

The term security connotes different meanings to different people in different social, political, and historical contexts. It has been most commonly used in the field of international relations to associate with military conflicts among nations. According to Arnold Wolfers, "security, in an objective sense, measures the absence of threats to acquired values, in a subjective sense, the absence of fear that such values will be attacked" (Wolfers 1962: 150). Since the concept of security, which was traditionally associated with military affairs, broadened to include non-military security issues such as environmental, economic, political, and cultural security concerns, controversies have arisen about the desirability of attaching a "security" modifier to non-military concerns. The debate about environmental concerns has been particularly intense (Brown 1989; Mathews 1989; Myers 1989; Pirages 1995; Ullman 1983; Wirth 1989).

Numerous publications have addressed the issue of climate security, including journal papers, governmental documents, and conference reports. Many studies have also aimed at categorizing definitions and approaches of climate security (Gleditsch 1998; Kawashima and Akino 2001; Levy 1995; McDonald 2013; Trombetta 2008; von Lucke et al. 2014; WBGU 2007). Four types of approaches emerged from our study of the existing literature. They respectively focus mainly on (1) long-term global impacts, (2) short-term local or regional impacts, (3) effects on conflict and violence, and (4) effects on national security.

\section{Long-term irreversible planetary changes}

The first category includes discussions of the long-term nature of climate change as a new threat that could cause dramatic changes at the planetary level. The world is already more than $1{ }^{\circ} \mathrm{C}$ warmer than the pre-industrial period (World Meteorological Organization 2015), and it may continue to get even warmer if necessary actions are not taken (IPCC 2014). This approach rarely accounts for national security or the nation-state as a unit of protection. Rather, it emphasizes the importance of universal action to tackle global crises to protect our next generation and other living things on Earth (Methmann and Rothe 2012; Rothe 2011). In this respect, this approach is quite different than the typical perspective of national security experts, who naturally consider the nation-state to be an object of protection. Mobjörk et al. (2016) also categorized the climate security discourse into four types of approaches and named this the "climate-related change" approach, which focused on "changes in biophysical 
conditions that are or will be affected by a change in the state of the climate or by variations in the mean state of the climate" (Mobjörk et al. 2016: 5).

Attempts have been made to broaden the security agenda to include various issues that would attract more political attention. The work of the Copenhagen School is relevant to this approach because it considered the implications of broadening the security agenda and specifically dealt with the climate change problem as a security issue (Buzan 1991). Moreover, the work of the Copenhagen School has been influential in the academic debate, with its role of warning about the risk of framing global climate change and other environmental problems in security terms.

\section{Short-term abrupt risks to individuals}

Publications in the second category are focused more on individual and community risk management in the shorter term. Adverse impacts of climate change include extreme weather events such as floods, droughts, and extremely hot or cold temperatures, all of which can be seen as threats to individuals (Vogler 2013). Mobjörk et al. (2016) named this approach the "comprehensive security approach", which is built upon as a human security approach but also addresses the interplay between different dimensions of security, such as energy security and food security. Negative effects, such as malnutrition, unsanitary conditions, and temporary displacement of people were categorized into this approach. In most cases, this approach had been applied to individuals living in developing countries. In recent years, however, it has become more applicable to individuals in developed countries because more extreme weather events have begun to affect local areas in those countries.

Dalby (2013) argued that climate change has added a new impetus and urgency to the long-running discussion of environmental security and that this requires consideration of three themes in particular: urban vulnerabilities, unforeseen social and political consequences of adaptation and mitigation efforts, and possibilities of geo-engineering. In a sense, this approach advises people to prepare for the worst-case situations and build resilience to the impacts of climate change. Unlike the notion of defense, the resilience discourse is not dependent on a "friend-enemy" logic and the dangers that follow from the creation of political antagonisms (Corry 2014).

\section{Cause of conflict and violence}

The third approach focuses on conflict between people and emphasizes that the causes of such conflict originate from climate change. Although the term "climate" is used, this approach is most concerned about conflict between groups of people, often in developing countries. Several early case studies conducted in different parts of the world studied how environmental degradation can lead to regional conflict (Gleick 1993; Homer-Dixon 1991, 1999). The report of Germany's Advisory Council on Global Change (WBGU 2007) dealt with the climate security debate mainly using this approach, and it identified six key threats to international security and stability that could arise through the failure of climate change mitigation. In later years, adelphi, a Germanbased think tank used the term "climate fragility risks" when investigating a potential cause of conflict in the Lake Chad Basin in a case with climate-change-induced environmental degradation and social instability (Nagarajan et al. 2018).

As the case studies and relevant discourses using this approach accumulated, it became apparent that conflict occurred in some of the areas where environmental changes occurred, but the changes did not always lead to conflict (Baechler 1998; Boas 2015; Hartmann 2010; Kelly et al. 2015; Selby and Hoffmann 2016). Nevertheless, although the relationship may not be direct and simple, the impact of climate change may stimulate conflict between people that might not have happened if it were not for such changes (Purvis and Busby 2004).

\section{Impacts on military and defense organizations}

The fourth approach is rooted in a national security perspective, where climate change is assumed to be a threat to national security and military operations. This approach was mostly found in literature from the United States. Both the US government and various think tanks have published reports on climate security. Some of the reports emphasized planetary changes, similar to the first approach, but they focused on how such planetary changes could completely alter the existing state of US national security (National Intelligence Council 2016; Schwartz and Randall 2003; White House 2015). Other reports were more specifically interested in considering the implications to US national security, including how its military operations could be affected by climate change, how much instability could be anticipated through the displacement of people overseas, and how much damage could be incurred by US military sites (CNA Corporation 2007; Department of Defense 2019).

Other countries, including the United Kingdom (United Kingdom 2015) and New Zealand (Ministry of Defence, New Zealand 2018), have also reported on national security strategy with repeated references to climate change. The United Kingdom also proposed a discussion on climate change at the UN Security Council for the first time in 2007, and other countries have also since joined in the request. The issue of climate change has since regularly been on the Security Council's agenda. 
Table 1 Summary of the four categories of climate security discourse

\begin{tabular}{|c|c|c|c|}
\hline Category & Threat & Objects of protection & Means to improve level of security \\
\hline $\begin{array}{l}\text { Long-term irreversible planetary } \\
\text { changes }\end{array}$ & $\begin{array}{l}\text { Global changing climate, warming } \\
\text { world }\end{array}$ & $\begin{array}{l}\text { The planet, human beings, and the } \\
\text { ecosystem }\end{array}$ & $\begin{array}{l}\text { GHG emission reduction at global } \\
\text { level (mitigation policy) }\end{array}$ \\
\hline $\begin{array}{l}\text { Short-term abrupt risks to indi- } \\
\text { viduals }\end{array}$ & $\begin{array}{l}\text { Extreme weather events and other } \\
\text { impacts of climate change at the } \\
\text { regional and individual levels }\end{array}$ & $\begin{array}{l}\text { People's daily life, including stable } \\
\text { supply of basic human needs }\end{array}$ & $\begin{array}{l}\text { Adaptation measures, building } \\
\text { resilience }\end{array}$ \\
\hline Cause of conflict and violence & $\begin{array}{l}\text { Migration and other causes of } \\
\text { conflict between groups }\end{array}$ & Own group & Reduction of social instability \\
\hline $\begin{array}{l}\text { Impacts on military and defense } \\
\text { organizations }\end{array}$ & $\begin{array}{l}\text { Long-term changes, such as } \\
\text { sea-level rise, and short-term } \\
\text { changes, such as extreme } \\
\text { weather events }\end{array}$ & $\begin{array}{l}\text { National territory, military facili- } \\
\text { ties, and defense forces }\end{array}$ & $\begin{array}{l}\text { Adaptation in the area of defense } \\
\text { and other military operations }\end{array}$ \\
\hline
\end{tabular}

\section{Comparison of the four approaches}

Table 1 summarizes the four approaches. Here, we highlight what is assumed as threat and what is assumed to be protected from the threat so that the differences between the four categorizations are clearer. The four approaches also eventually send different messages on how insecure conditions can be mitigated.

The first approach considers the changing climate in the long term to be a serious threat, not to the national security of any one country, but to future generations and all other living things in the global ecosystem. Advocates of this approach are worried that the progression of climate change could render Earth uninhabitable. The term "security" is used to alert other people who are less aware of the danger. The only way to avoid the crisis is to mitigate climate change by reducing GHG emissions. Article 2 of the Paris Agreement states "holding the increase in the global average temperature to well below $2{ }^{\circ} \mathrm{C}$ above pre-industrial levels and to pursue efforts to limit the temperature increase to $1.5^{\circ} \mathrm{C}$ " is the long-term goal of the agreement. Such a goal is needed from the viewpoint of this approach.

The second approach considers extreme weather events and other impacts of climate change at the regional level as a threat to individuals. Even if the impacts are not directly life threatening to individuals, their daily lives could be seriously damaged by events such as floods and hurricanes. Extremely high temperatures and epidemics of diseases such as dengue fever and malaria could have serious health implications, and the food and water supply could be limited by serious droughts. All these concerns are less relevant to national security and much more related to human security, food security, and water security. In this approach, therefore, people must be well prepared for the risks. Dikes could be built to prevent floods, and food banks could be built up so that people will not starve even during the worst droughts. These measures are part of "adaptation" in climate changerelated terminology. In Article 7 of the Paris Agreement, all countries are to engage in adaptation planning processes and the implementation of relevant actions.

The third approach is much more focused on the interactions among the impacts of climate change, the displacement of people, and conflict in socially unstable regions. With this approach, "threat" originates from people outside of your own community. Displaced people may immigrate due to damages caused by climate change, and the immigration could raise tensions between various groups of people, including the original residents of an area and the new immigrants. It is recognized, however, that the impacts of climate change do not always lead to conflict. Rather, conflict occurs in the areas that were socially fragile even before climate change. To avoid conflicts, therefore, regions need to increase social stability by improving the level of governance and building resilience to natural hazards.

The fourth approach employs a narrower definition of security, one in which national security is conducted by the military. Traditionally, national security has been concerned with other countries' armed forces and other similar threats to a nation state. With "climate security", however, the threat has been expanded to include a wide variety of impacts of climate change. These include longterm events such as sea-level rise, which could change the shape of national territories and exclusive economic zones (EEZs), or melting of the Arctic ice-sheet, which could completely change navigation routes for military and other ships. They also include short-term extreme weather patterns such as floods and hurricanes that could damage military facilities. To avoid these losses, those using this approach emphasize the importance of military and national security strategies to take into account the impacts of climate change.

Although we categorized the climate security concept into four groups to facilitate our examination of Japanese interpretation in the next section, that does not mean the four groups are completely independent of each other 
(Yamada 2017). For example, through international cooperation on humanitarian assistance, prevention measures taken against sea-level rise and extreme weather events classified under the second approach can also be effective in minimizing migration and preventing conflict among people. In addition, from the point of view of the armed forces, climate mitigation and adaptation can be effective in reducing military operations other than war (Headquarters, Department of the Army 1993).

\section{Examination of climate security-related discourse in Japan by approach}

Here, we discuss the Japanese discourse by category and also some potential consequences of the absence of any security discourse as it relates to each of the categories.

\section{Long-term irreversible planetary changes}

Discourse in Japan related to this approach was conducted mostly as part of discourse related to climate mitigation policies. To convince Japanese industries and other stakeholders unwilling to reduce GHG emissions because emission reductions could hamper their economic activities, government officials and scientific experts emphasized the urgency of the problem by explaining the physical impact of climate change, but they did so without using the term "climate security".

The Ministry of the Environment (MOE) has been mainly responsible for management of the climate change problem. However, once the climate change issue had become part of the political agenda in the late 1980s, other ministries also became involved in the decision-making process. Because nearly $90 \%$ of Japan's GHG emissions are $\mathrm{CO}_{2}$ emissions from fuel combustion (Government of Japan 2017), the Ministry of International Trade and Industry (now the Ministry of Economy, Trade and Industry), which was responsible for energy policy, also was involved each time Japan set a GHG emission reduction target.

The purpose of reducing GHG emissions is to minimize the global temperature increase and other adverse effects of climate change. Whenever the Japanese government discussed its GHG emission reduction targets, the discussion inevitably started with a sentence explaining the significance of tackling climate change globally. When it came to determining Japan's emission reduction targets, however, the discourse almost always moved towards how Japan could make further improvements in energy efficiency rather than reducing absolute amount of emissions (Kameyama 2017; Tiberghien and Schreurs 2007). This tendency did not change, even as many countries negotiated the Kyoto Protocol in 1997. Japan compared its emission reduction target with those of the EU, the United States, and China, and asserted that Japan's emission reduction rate should be less than those of other developed countries because Japan was already more energy efficient than the other countries in terms of energy consumption per GDP or per capita (Kawashima 2000). Many Japanese stakeholders also insisted that emissions should be reduced in other countries where energy was being wasted. Overall, among Japanese policymakers, the climate change problem was perceived as an energy-saving problem and not as a security-related issue. Today, Japanese people and industry in general understand the basics of the climate change problem, but most of them still relate it to using as little energy as possible in everyday life (Danish Board of Technology Foundation 2015).

It is difficult to imagine what would have happened if the Japanese government had used the term "climate security" in its earlier climate dialog. Japan's first experience with the notion of climate security occurred in 2007 when the Ministry of Foreign Affairs (MOFA) had to deal with a UK proposal to include "climate and security" in an agenda of the UN Security Council (UN Security Council 2007). At that time, MOFA had considered the risks associated with climate change to be outside the scope of its traditional notion of "security" and thus did not enthusiastically support the UK proposal.

Meanwhile, the MOE received the UK's security proposal with greater interest and established a new committee to discuss the idea. The committee's final report (MOE 2007) introduced the discourse on climate security that had already been frequently heard outside Japan and emphasized that both mitigation and adaptation are needed to securitize Japan and Japanese citizens from the threats associated with climate change. The report also noted that use of the term "climate security" could help to elevate the discussion of the climate change problem to "high politics" and thereby enable the climate change agenda to gain a higher priority in international politics. Furthermore, the report highlighted that a sea-level rise of one meter would mean that megacities in Japan, including Tokyo and Osaka, would be flooded. In addition, a small island in south Tokyo called Okinotorishima would be completely submerged, causing the loss of a large area of Japan's EEZ in the Pacific Ocean.

The MOE, however, did not continue using the term "climate security" after publication of the report, which could be interpreted to mean that the ministry was not interested in using the term or concept to convince the Japanese people about the importance of climate change. They could have been concerned about causing confusion amongst Japanese people who think of traditional national security when the term anzen hosho (security) is used. Furthermore, the term 
"global security" is never used in Japan. In addition, national security falls under the authority of the Ministry of Defense (MOD), and the MOE may not have wanted to risk dealing with an issue that could be sponsored by other ministries (Yamaguchi 2017).

\section{Short-term abrupt climate change risks}

The existing discourse related to this approach is mostly related to food, water and energy security, human security, and adaptation in Japan. In terms of food and energy security, Japan has had a long experience of discussion under the notion of sogo anzen hosho (comprehensive security). The Japanese Constitution enacted in 1947 defines the right to live as "the right to maintain the minimum standards of wholesome and cultured living" in Article 25, which is modeled after Article 151 of the Weimar Constitution of 1919, which first introduced the concept of the right to live. The common understanding at the time was that the right to live was secured through economic policy and though national security policies, related mainly to diplomacy and defense.

In the 1980s, however, then Prime Minister Masayoshi Ohira used this term to cover various economic issues, including energy and food scarcity. A final report from his study group defined comprehensive security as the protection of "the people's daily life from various threats" (Sogo Anzen Hosho Kenkyu Guruupu 1980). The report often referred to energy security as it relates to an oil shortage and touched upon coal as an alternative source of energy but expressed environmental concerns about its use. Natural disasters were also mentioned in the document, but no explicit descriptions were given as to what kind of natural disasters were assumed. The ultimate motivation of introducing the notion of comprehensive security was the continuation of economic growth, and there were no references to any other type of risks, such as extreme weather events, that could indirectly affect energy and food supplies (Nakanishi 1998). However, after the release of the report, in academic discussions in the 1980s and 1990s, climate problems were still not included in the objectives of sogo anzen hoso (Arisawa and Saeki 1981; Eto and Yamamoto 1991). It took some time for MOFA and MOD to accept that the term security had a larger scope, but they also gradually changed their positions (Yamaguchi 2017).

The Japanese government also responded positively to a report by the United Nations Development Program (1994) that referred to human security, and MOFA has continued to support this dimension of diplomacy since then. For example, the Japanese government strongly recommended Sadako Ogata, former High Commissioner of the United Nations High Commissioner for Refugees from 1991 to 2000, to co-chair the Commission on Human Security with Amartya Sen (MOFA 2003). Although MOFA still places great importance on the human security-related agenda, the climate change issue is not considered as part of human security.

Similarly, MOFA also puts a great deal of effort into disaster-relief-related humanitarian relief. Japan prioritized disaster relief activities after a serious earthquake hit Hyogo prefecture in 1995. The Hyogo Framework for Action was adopted as part of the UN International Strategy for Disaster Reduction (UNISDR) in 2005 to build resilience in communities that could be subject to natural disasters (UNISDR 2005). In general, Japan was more interested in this kind of disaster relief because disasters could happen even without any reference to climate change. Due to its experience with serious earthquakes, Japan was better able to understand the importance of resilience building, regardless of any connection to climate change. The Japan International Cooperation Agency (JICA), mainly responsible for development assistance in developing countries, published a climate change cooperation strategy, which took climate change risks into consideration (JICA 2016). The report referred to "security" when discussing climate change as a human security issue and did not otherwise use the term. To minimize climate risks in developing countries, JICA stated that assistance will be important to help build capacity and physical facilities in preparation for prompt action in the event of emergencies.

After the adoption of the Paris Agreement in 2015, MOE started considering adaptation measures in Japan, whereas before the agreement, Japan and many other developed countries had mostly considered mitigation measures. Prior to this, adaptation had been thought to be primarily needed in poor countries in which society was less resilient and more fragile. This notion slowly changed to the point that the Paris Agreement contains an article that requires countries to establish an adaptation plan. The MOE published the first Adaptation Plan, which was adopted by the Cabinet in November 2015, just before the adoption of the Paris Agreement (MOE 2015). In June 2018, the Adaptation Law was adopted by the National Diet. Under the new law, national and local governments are required to design adaptation plans and inform citizens of the types of risks that people would most likely be exposed to in the relevant region. The law requires that scientific findings by Japanese experts be fully utilized to estimate impacts of climate change including future temperature rises and changes in precipitation patterns for local communities so they can prepare for the changes.

For the Japanese people, the notions of energy security and food security can be interpreted as important issues in terms of fulfilling their own basic human needs before climate change became a national issue. On the other hand, after being hit by serious earthquakes twice in the last quarter-century, people in Japan have been prepared for natural 
disasters in general, regardless of whether the disaster was caused by climate change or an earthquake. Securing the supplies of food and energy to meet basic human needs in daily life, preparing for natural disasters caused by earthquakes, and preparing for other types of disasters resulting from climate change are logically three distinctly different objectives, but they are perceived as a single notion by the public. In this respect, the use of the term "climate security" could evoke confusion rather than encourage a deeper understanding to make substantial changes to policy responses to climate change in Japan.

One element that was consistently missing in Japan's discourse under this approach was any discussion of short-term abrupt climate change risks outside Japan, such as in countries in the Asia-Pacific region, which could indirectly affect Japan's economy via supply chains. As was experienced after a serious flood in Thailand in 2011, Japanese industries can be seriously affected economically by the impacts of climate change outside of Japan (Fetzek et al. 2019).

\section{Cause of conflict and violence}

Surprisingly, almost no discourse has been conducted in Japan from the perspective of this approach. Interestingly, conflict has already arisen over fish catchment areas among Japan, China, Korea, and Russia, and this issue has contributed to worsening relationships among these countries. Furthermore, warming seawater is likely to shift the fish habitat areas, which could become another controversial issue among these countries (Garret et al. 2016). Nevertheless, relevant agencies within Japan, such as the Japanese Fisheries Agency, have never officially referred to any possible existing or future conflicts as being a result of the impact of climate change.

At a G7 Foreign Ministers' Meeting in 2013, the member countries agreed to initiate a discussion on climate fragility risks. Japan, the only G7 member country in the Asia-Pacific region, decided to work on climate-related risks that could occur in that region (MOFA 2017). MOFA's analysis indicated the nexus between impact of climate change and social fragility in the Asia-Pacific region, which has proved to be an important finding for the Japanese government when planning overseas development aid and humanitarian assistance in the region. This is a rare example of an official position paper from the government on climate change from the aspect of social instability.

As a part of Japanese foreign policy towards Asia-Pacific countries, human security and disaster management were the two pillars used to conduct humanitarian assistance for people affected by natural disasters. The current Japanese assistance scheme has paid little attention to social instability, primarily because the connection between climate change and conflict has yet to be fully proven (Busby 2019).
The government's existing actions would be sufficient if the anticipated risks were only physical risks such as those related to floods, food supply, and sanitation. However, in reality, social risks such as violence and conflict between people could arise in affected areas, and using the term "climate security" could be one way to initiate discussion on this topic.

Japan has accepted very few immigrants for economic and political reasons. Unlike in Australia and New Zealand (Merone and Tait 2018), where the existence of climate refugees has already become an issue, Japan has not experienced environmental immigration, perhaps due to the relatively longer distance from the small Pacific Island states. Thus, it is difficult for the Japanese people to imagine a large number of displaced refugees flowing into Japan as a result of climate change, even as the size of the displaced population due to climate change is growing around the world and in the Asia-Pacific region. It is crucial for Japan to start discussing how it will participate in this migration debate, and using terms such as "climate security" in this context could help kick-off such discussions.

\section{Military-related issues}

Debates about national security are mainly within the realm of the MOD in Japan. The MOD pays almost no attention to issues it deems as having little relation with military matters, and climate change is one such issue. The Basic Policy of National Defense, adopted in 1957, has formed the basis of the Japanese national defense strategy. The document was replaced by the National Security Strategy (NSS), which was approved by the Cabinet in 2013 (Cabinet Secretariat 2013) and covered a wide range of security issues. Climate change was mentioned as one of those issues, but the document merely proposed that the promotion of Japanese technologies for the purpose of GHG emission mitigation was the appropriate way to respond to the climate change issue. The document also referred to human security and disaster relief, but without directly mentioning climate change.

The Cabinet also adopted the National Defense Program Guidelines, and two guidelines have been adopted under the current NSS (MOD 2013, 2018), but both of these covered only military aspects of security and did not mention any wider security context. There was a brief reference to climate security in a Defense White Paper in 2008, which briefly explained events at the UN Security Council in 2007 and a few other relevant discussions (MOD 2008). In 2009, a publication by the National Institute for Defense Studies (NIDS), a research arm of the MOD, included a chapter on climate change, energy, food, and security for the first time (NIDS 2009). The chapter summarized discourse related to climate security outside Japan and how such discourse is related to other types of security such as energy and food 
security. It did not go so far as to make any policy recommendation as to how Japan should respond to the idea of climate security.

The only area where the impact of climate change has affected activities of the Japanese Self-Defense Force lies in overseas humanitarian assistance in case of severe natural disasters. In the 2010s, experts in the field of disaster relief by the Self-Defense Force began to publish reports on the topics of security policy and humanitarian assistance activities within Japan. These reports took up the issue of linkages between increasing extreme weather events, disaster relief, and foreign humanitarian assistance by the Japanese government (Ono 2012; Yamaguchi 2018). Most of them paid little attention to the relationship between climate change and extreme weather events. Rather, they merged all types of natural disasters, including climate change and earthquakes, and discussed how the Japanese military could help other countries in case of serious disasters. However, the severity and frequency of natural disasters in Asia have increased in recent years, and some individuals related to the Japanese Self-Defense Force are starting to indicate their limited capacity to respond to these incidents (Tebbe 2018).

As noted above, the MOE report on climate security (MOE 2007) was the only official report from the Japanese government that referred to possible flooding of megacities in Japan or the loss of a large area of Japan's EEZ in the Pacific Ocean due to sea-level rise. Almost no other discussion has occurred officially among Japanese governmental ministries. In addition, very few discussions are conducted by Japanese think tanks on climate-related security issues. One informal workshop hosted by a Japanese think tank suggested the possible impacts of ice-melting in the Arctic and how they could affect Japan-China-Russia relations (CIGS 2017). Potential undiscussed problems include the geopolitical implications of climate change, such as other impacts on Japan-China-Korea relations, including sovereignty over the Senkaku Islands and other small islands. In addition, Japan has military bases in coastal areas, which could be damaged by high tides and storms exacerbated by climate change. Japan's military is increasingly being dispatched for humanitarian assistance in developing countries, and this is likely to increase even more in the future. Discussions need to begin on how such military operations could be conducted in an efficient manner under a changing climate.

\section{Conclusions}

In some areas, climate change policies and dialog in Japan have dealt with important issues using terms and concepts such as climate change mitigation, adaptation to climate change, human security, food security, and disaster management. These are climate-security-related concepts that fall into the first and the second categories of climate security shown in Table 1. This means that Japanese stakeholders have not perceived the needs to use the term "climate security" as they continue discussions of these kinds of impacts and dimensions of climate change, because they consider that the Japanese people either already are or will become aware of these risks even without using the term. They may fear introduction of the concept "climate security" could obfuscate the important nuances of these risks. On the other hand, we were able to identify areas where security discourse is absent or severely lacking in Japan. These include discussions of any possible geopolitical implications of climate change in Japan, displacement of people and possible migration into Japan, and potential social instability, particularly in the Asia-Pacific region. In addition, discussion of the impact of climate change on Japan's military facilities has been negligible. It is of utmost importance for Japan to begin a discourse in these fields and to do so by introducing the notion of climate security.

The categorization of the four approaches of climate security developed in this study was useful in analyzing Japanese discourse related to climate change. Although several studies had developed different types of climate security in the past, few, if any, had gone so far as to clarify the underlying messages to mitigate insecure conditions, and to compare among different types of notion of climate security. This could be a reason why several climate security researchers are critical of use of the term "climate security" (Detraz and Betsill 2009; Deudney 1990; Floyd 2010; Levy 1995). Many of them have criticized one or two of the four approaches, without examining the significance of the other approaches. Confusion among users of the term "climate security" about the various approaches to climate security could undermine efforts to understand the real implications of climate change as a threat. The approach adopted in this study could also be useful in examining how countries other than Japan discuss and respond to climate change risks. One remaining research goal could be to examine interactions and relationships among the four categories of climate security. For example, the idea of a "threat multiplier" has been proposed by several researchers (adelphi 2015; CNA Corporation 2007) in which one type of threat caused by climate change may induce another type of threat. The use of the idea of "climate security" could become an effective strategy to promote a better understanding of both the physical and social impacts of climate change in different cultural contexts.

Acknowledgements This research was performed by the Environment Research and Technology Development Fund (JPMEERF20182001) of the Environmental Restoration and Conservation Agency of Japan.

Open Access This article is licensed under a Creative Commons Attribution 4.0 International License, which permits use, sharing, adaptation, distribution and reproduction in any medium or format, as long 
as you give appropriate credit to the original author(s) and the source, provide a link to the Creative Commons licence, and indicate if changes were made. The images or other third party material in this article are included in the article's Creative Commons licence, unless indicated otherwise in a credit line to the material. If material is not included in the article's Creative Commons licence and your intended use is not permitted by statutory regulation or exceeds the permitted use, you will need to obtain permission directly from the copyright holder. To view a copy of this licence, visit http://creativecommons.org/licenses/by/4.0/.

\section{References}

adelphi (2015) A new climate for peace: taking action on climate and fragility risks, an independent report commissioned by the G7 members. https://www.newclimateforpeace.org/. Accessed 20 Jan 2020

Adger WN (2010) Climate change, human well-being, and insecurity. New Polit Econ 15(2):275-292

Arisawa H, Danwakai KT (eds) (1981) Nihonkeizaito Sogo anzen hosho (Japanese economy and comprehensive security). University of Tokyo Press, Tokyo (in Japanese)

Baechler G (1998) Why environmental transformation causes violence: a synthesis. Environmental Change and Security Project Report Issue 4, Spring 1998, pp 24-44

Boas I (2015) Climate migration and security: securitisation as a strategy in climate change politics. Routledge, New York

Brown N (1989) Climate, ecology and international security. Survival 31(6):519-532. https://doi.org/10.1080/00396338908442497

Busby J (2019) The field of climate and security: a scan of the literature. The Social Science Research Council (SSRC), April 2019

Buzan B (1991) People, state and fear: an agenda for international security studies in the post-cold war era. Harvester Wheatsheaf, London

Buzan B, Waver O, de Wilde J (1998) Security: a new framework for analysis. Lynne Rienner, Boulder

Cabinet Secretariat (2013) National security strategy. December 17, 2013. https://www.cas.go.jp/jp/siryou/131217anzenhoshou/nss-e. pdf. Accessed 5 Mar 2019

CIGS (The Canon Institute for Global Studies) (2017) Dai26kai CIGS Seisaku Shimyureshon (The 26th CIGS Policy Simulation) report. August 2017 CIGS Diplomacy and Security Group. https://www. canon-igs.org/research_papers/170823_miyakeU_report.pdf. Accessed 5 Mar 2019 (in Japanese)

CNA Corporation (2007) National security and the threat of climate change (Alexandria: VA: CNA corporation). https://www.npr.org/ documents/2007/apr/security_climate.pdf. Accessed 20 Mar 2019

Corry O (2014) From defense to resilience: environmental security beyond neo-liberalism. Int Polit Sociol 8:256-274. https://doi. org/10.1111/ips.12057

Dalby S (2013) Climate change: new dimensions of environmental security. RUSI J 158(3):23-32. https://doi.org/10.1080/03071 847.2013.807583

Danish Board of Technology Foundation (2015) World wide views on climate and energy. Results Report. https://www.climateandenerg y.wwviews.org. Accessed 20 Mar 2019

Department of Defense (2019) Report on effects of a changing climate to the department of defense, as required by section 335 of the National Defense Authorization Act for Fiscal Year 2018. https:// climateandsecurity.files.wordpress.com/2019/01/sec_335_ndaareport_effects_of_a_changing_climate_to_dod.pdf. Accessed 20 Mar 2019
Detraz N, Betsill MM (2009) Climate change and environmental security: for whom the discourse shifts. Int Stud Perspect 10(3):303320. https://doi.org/10.1111/j.1528-3585.2009.00378.x

Deudney D (1990) The case against linking environmental degradation and national security. Millenn J Int Stud 19(3):461-476. https:// doi.org/10.1177/03058298900190031001

Diez T, von Lucke F, Wellman Z (2016) The securitization of climate change: actors, processes, and consequences. Routledge, London, New York

Eto S, Yamamoto Y (1991) Sogoanpo to mirainosentaku (comprehensive security and the choice for the future). Kodansha, Tokyo (in Japanese)

Fetzek S, Fleishman R, Conger J (2019) Japanese industry in an unstable climate: reducing exposure to the security implications of climate change. Center for Climate and Security May 2019. https:// climateandsecurity.files.wordpress.com/2019/05/japanese-indus try-in-an-unstable-climate_reducing-exposure-to-the-securityimplications-of-climate-change_2019_5-1.pdf. Accessed 10 July 2019

Floyd R (2010) Security and the environment, securitisation theory and US Environmental Security Policy. Cambridge University Press, Cambridge

Floyd R, Matthew RA (eds) (2013) Environmental security: approaches and issues. Routledge, London, New York

Garret A, Pinnegar J, Buckley P (2016) Climate change adaptation in the UK seafood industry: a Seafish/MCCIP watching brief report. Marine Climate Change Impacts Partnership

Gleditsch NP (1998) Armed conflict and the environment: a critique of the literature. J Peach Res 35(3):381-400

Gleick P (1993) Water and conflict—fresh water resources and international security. Int Secur 18(1):79-112

Government of Japan (2017) Japan's third biennial report under the United Nations framework convention on climate change. December 2017

Hartmann B (2010) Rethinking climate refugees and climate conflict: rhetoric, reality and the politics of policy discourse. J Int Dev 22:233-246. https://doi.org/10.1002/jid.1676

Hattori T (2007) The rise of Japanese climate change policy: balancing the norms economic growth, energy efficiency, international contribution and environmental protection. In: Pettenger ME (ed) The social construction of climate change, power, knowledge, norms, discourses. Ashgate, Aldershot, pp 75-97

Headquarters, Department of the Army (1993) Field manual 100-5. June 1993. Available on line at https://www.bits.de/NRANEU/ others/amd-us-archive/fm100-5\%2893\%29.pdf. Accessed 3 Feb 2020

Homer-Dixon T (1991) On the threshold: environmental changes as causes of acute conflict. Int Secur 16(2):76-117

Homer-Dixon T (1999) Environment, scarcity and violence. Princeton University Press, Princeton

IPCC (Intergovernmental Panel on Climate Change) (2014) Climate change 2014: synthesis report. Contribution of working groups I, II and III to the fifth assessment report of the Intergovernmental Panel on Climate Change, Geneva, Switzerland, IPCC

JICA (Japan International Cooperation Agency) (2016) JICA climate change cooperation strategy. https://www.jica.go.jp/english/ our_work/climate_change/c8h0vm00005rzelb-att/strategy_01. pdf. Accessed 20 Mar 2019

Kagawa-Fox M (2012) The ethics of Japan's global environmental policy. Routledge, Abingdon

Kameyama Y (2017) Climate change policy in Japan. Routledge, Arbindon

Kawashima Y (2000) Japan's decision-making about climate change problems: comparative study of decisions in 1990 and in 1997. Environ Econ Policy Stud 3(1):29-57 
Kawashima Y, Akino S (2001) Climate change and security: regional conflict as a new dimension of impact of climate change. Glob Environ Res 1:33-430

Kelly CP, Mohtadi S, Cane MA, Seager R, Kushnir Y (2015) Climate change in the Fertile Crescent and implications of the recent Syrian drought. PNAS 112(11):3241-3246. https://doi.org/10.1073/ pnas. 1421533112

Levy M (1995) Is the environment a national security issue? Int Secur 20(2):35-62. https://doi.org/10.2307/2539228

Mathews JT (1989) Redefining security. Foreign Aff Spring 1989:162-177

McDonald M (2013) Discourses of climate security. Polit Geogr 33:42-51. https://doi.org/10.1016/j.polgeo.2013.01.002

Merone L, Tait P (2018) 'Climate refugees': is it time to legally acknowledge those displaced by climate disruption? Aust NZ J Public Health 42(6):508-509. https://doi. org/10.1111/1753-6405.12849

Methmann C, Rothe D (2012) Politics for the day after tomorrow: the political effect of apocalyptic imageries in global climate governance. Secur Dialogue 43(4):323-344

Ministry of Defence, New Zealand (2018) The climate crisis: defence readiness and responsibilities. Ministry of Defence. https://defen ce.govt.nz/assets/Uploads/Climate-Change-and-Security-2018. pdf. Accessed 20 Mar 2019

Mobjörk M, Gustafsson MT, Sonnsjö H, van Baalen S, Dellmuth LM, Bremberg N (2016) Climate-related security risks: towards and integrated approach. SIPRI Publications. https://www.sipri.org/ publications/2016/climate-related-security-risks. Accessed 20 Mar 2019

MOD (Ministry of Defense) (2008) Boei Hakusho (Defense White Paper) 2008. MOD. https://www.clearing.mod.go.jp/hakusho_ data/2008/2008/index.html. Accessed 20 Mar 2019 (in Japanese)

MOD (Ministry of Defense) (2013) National defense program guidelines for FY 2014 and beyond. MOD, 17 December 2013. https ://www.mod.go.jp/j/approach/agenda/guideline/2014/pdf/20131 217 e2.pdf. Accessed 20 Mar 2019

MOD (Ministry of Defense) (2018) National defense program guidelines for FY 2019 and beyond. MOD, 18 December 2018. https ://www.mod.go.jp/j/approach/agenda/guideline/2019/pdf/20181 218_e.pdf. Accessed on 20 Mar 2019

MOE (Ministry of the Environment) (2007) Kiko anzen hoshouni kansuru Houkoku (Report on Climate Security). https://www.env. go.jp/earth/report/h19-01/index.html. Accessed 20 Mar 2019 (in Japanese)

MOE (Ministry of the Environment) (2015) Kiko Hendo no Eikyo heno Tekiou Keikaku (Adaptation plan against impact of climate change). 27 November 2015. https://www.env.go.jp/earth/ondan ka/tekiou/siryo1.pdf. Accessed 20 Mar 2019 (in Japanese)

MOFA (Ministry of Foreign Affairs) (2003) Submission of report by Commission on Human Security to Secretary-General of the United Nations Kofi Annan. https://www.mofa.go.jp/policy/ human_secu/commission/report0305.html. Accessed 20 Mar 2019

MOFA (Ministry of Foreign Affairs) (2017) Analysis and proposal of Foreign Policies regarding the impact of climate change on fragility in the Asia-Pacific region-with focus on natural disasters in the region. September 2017. https://www.mofa.go.jp/files/00028 7344.pdf. Accessed 20 Mar 2019

Myers N (1989) Environment and security. Foreign Policy Spring 1989:23-41

Nagarajan C, Pohl B, Rüttinger L, Sylvestre F, Vivekananda J, Wall M, Wolfmaier S (2018) Climate-fragility profile: Lake Chad Basin. adelphi, Berlin

Nakanishi H (1998) Redefining comprehensive security in Japan. In: Kokubun R (ed) Challenges for China-Japan-US cooperation. Japan Center for International Exchange, Tokyo, New York, pp 44-69
National Intelligence Council (2016) Implications for US national security of anticipated climate change. NIC WP 2016.01, 21 September 2016

NIDS (National Institute for Defense Studies) (2009) Chapter 2: the security implications of climate, energy, and food issues. East Asian Strategic Review 2009, pp 43-68. https://www.nids.mod. go.jp/english/publication/east-asian/e2009.html. Accessed 20 Mar 2019

Ono K (2012) Civil-military medical assistance cooperation after the Great East Japan Earthquake, experiences and lessons. LIAISON 5:45-52

Pirages D (1995) Microsecurity: diseases organisms and human wellbeing. Wash Quart 18(4):5-12

Purvis N, Busby J (2004) The security implications of climate change for the UN system, policy brief, the United Nations and Environmental Security. ECSP Rep 10:67-73

Rothe D (2011) Managing climate risks or risking a managerial climate: state, security and governance in the international climate regime. Int Relat 25(3):330-345

Schwartz P, Randall D (2003) An abrupt climate change scenario and its implications for United States security. Global Business Network, Washington DC

Selby J, Hoffmann C (eds) (2016) Rethinking climate change, conflict and security. Routledge, New York

Sogo Anzen Hosho Kenkyu Guruupu (Comprehensive Security Study Group) (1980) Sogo Anzen Hosho Kenkyu Guruupu Hokokusho (Comprehensive Security Study Group Report). 2 July 1980. https ://worldjpn.grips.ac.jp/documents/texts/JPSC/19800702.O1J. html. Accessed 20 Mar 2019

Tebbe S (2018) Climate change remains a consistent theme at ShangriLa Security Dialogue, in The Center for Climate and Security. 19 June 2018. https://climateandsecurity.org/2018/06/19/climatechange-remains-a-consistent-theme-at-shangri-la-security-dialo gue/. Accessed 4 Apr 2019

Tiberghien Y, Schreurs MA (2007) High noon in Japan: embedded symbolism and post-2001 Kyoto protocol politics. Glob Environ Polit 7(4):70-91

Trombetta MJ (2008) Environmental security and climate change: analysing the discourse. Camb Rev Int Aff 21(4):585-602. https://doi. org/10.1080/09557570802452920

Ullman R (1983) Redefining security. Int Secur 8(1):129-153

United Nations Development Programme (1994). Human development report 1994. Oxford University Press, New York. https://hdr.undp. org/sites/default/files/reports/255/hdr_1994_en_complete_nosta ts.pdf. Accessed 20 Mar 2019

UNISDR (United Nations International Strategy for Disaster Reduction) (2005) Hyogo framework for action 2005-2015. Building the resilience of nations and communities to disasters. https:// www.unisdr.org/files/1037_hyogoframeworkforactionenglish.pdf. Accessed 20 Mar 2019

United Nations Security Council (2007) S/2007/186, Letter dated 5 April 2007 from the permanent representative of the United Kingdom of Great Britain and Northern Ireland to the United Nations addressed to the President of the Security Council, 5 April 2007

United Kingdom (2015) The UK national security strategy and strategic defence and security review 2015. https://assets.publishing .service.gov.uk/government/uploads/system/uploads/attachment _data/file/478933/52309_Cm_9161_NSS_SD_Review_web_only. pdf. Accessed 20 Mar 2019

Vogler J (2013) Changing conceptions of climate and energy security in Europe. Environ Polit 22(4):627-645

von Lucke F, Wellmann Z, Diez T (2014) What's at stake in securitising climate change? Towards a differentiated approach. Geopolitics 19(4):857-884

WBGU (2007) World in transition: climate change as a security risk. Earthscan, London, Sterling 
White House (2015) Findings from select federal reports: the National Security implications of a changing climate. May 2015. https ://obamawhitehouse.archives.gov/sites/default/files/docs/Natio nal_Security_Implications_of_Changing_Climate_Final_05191 5.pdf. Accessed 20 Mar 2019

Wirth D (1989) Climate chaos. Foreign Policy Spring 1989:3-22

Wolfers A (1962) Discord and collaboration: essays on international politics. John Hopkins University Press, Baltimore

World Meteorological Organization (2015) 2015 to be hottest year ever: World Meteorological Organization. https://theconversation .com/2015-to-be-hottest-year-ever-world-meteorological-organ ization-51310. Accessed 20 Mar 2019

Yamada T (2017) Chikyuukankyomondaino Anzenhoshokano Genkaitokanousei (The limit and potential of securitization of climate problems). Kokusai Anzenhosho (J Int Secur) 45(3):18-34 (in Japanese)
Yamaguchi W (2017) Sogoanzenhoshou no Juyou (Acceptance of Comprehensive Security). Kokusaiseiji (J Int Relat) 188:46-61 (in Japanese)

Yamaguchi N (2018) Saigaikyuenkatsudouniokeru Mingunrenkeito Nichibeidoumei-Taifu Haiyan no kesu (Public Engagement and Japan-US Alliance at the time of Disaster Relief Activities: a case of Typhoon Haiyan). In: Shinoda T (ed) Nichibei Dome to Tonan Ajia (Japan-US Alliance and Southeast Asia). Chikura Shobo, Tokyo, pp 123-153 (in Japanese)

Publisher's Note Springer Nature remains neutral with regard to jurisdictional claims in published maps and institutional affiliations. 